\title{
Tourism Development and Responsible Practices
}

\author{
Mohd Hafiz Hanafiah, Mohd Raziff Jamaluddin, Mohd Izzat Zulkifly \\ Universiti Teknologi MARA Malaysia \\ hafizhanafiah@salam.uitm.edu.my
}

\begin{abstract}
The responsible tourism practices have been identified as an ideal framework to sustain the growth and minimize the constructive effects of tourism development. To confirm the conjuncture, this study examines the moderating effect of responsible tourism practices on the relationship between tourism development and quality of life. Self-administered questionnaires were distributed using quota sampling. The collected data were tested with the reliability and validity analysis, and the research hypotheses are tested using multiple regression analysis. The study findings indicated that the residents' of Pangkor Island agreed that responsible tourism practices affect their quality of life positively.

Keywords: Responsible; tourism; practice; development

elSSN: 2398-4295 (C) 2016. The Authors. Published for AMER ABRA by e-International Publishing House, Ltd., UK.. This is an open access article under the CC BY-NC-ND license (http://creativecommons.org/licenses/by-nc-nd/4.0/). Peer-review under responsibility of AMER (Association of Malaysian Environment-Behaviour Researchers), ABRA (Association of Behavioural Researchers on Asians) and cE-Bs (Centre for Environment-Behaviour Studies), Faculty of Architecture, Planning \& Surveying, Universiti Teknologi MARA, Malaysia.

https://doi.org/10.21834/ajbes.v1i1.19
\end{abstract}




\subsection{Introduction}

Tourism products are incredibly diverse with potential business, cultural exchange, and income creation. It may generate various economic, ecological and socio-cultural impacts on the destination (Cottrell \& Vaske, 2006; Nadzir, Ibrahim, \& Mansor, 2014). Therefore, to manage the impact, the development process must be monitored carefully to balance the benefit to the stakeholder (Dyer, Gursoy, Sharma, \& Carter, 2007; Eshliki \& Kaboudi, 2012a; Sheldon \& Abenoja, 2001). One of the most flourishing tourism products in Malaysia is the island archipelagos that serve the tropical sense of nervousness, flora and fauna prosperity, culture diversity and friendly local host. Currently, there were 53 islands gazetted as Marine Parks and protected under the marine park act and ordinance (Pomeroy et al., 2015). The island of Malaysia continues to develop into tourist spots, attracting a continuous number of arrivals and delivering numerous positive effects such as enhancing local economies, being a source of new employment opportunities, additional tax receipts, foreign exchange benefits and revenue, tourism development. However, tourism development also contributed towards negative outcomes (Kariminia, Ahmad, \& Hashim, 2012; Ko \& Stewart, 2002).

More than 400,000 tourists visited Pangkor Island in 2012, with the demand is predicted to grow every year, leading towards harmful effect such as physical degradation, cleanliness, marine pollution and over coastal development. The rapid rate of development growth has affected the ecological and environmental components of the island (Liu, 2012). Furthermore, the rapid development process has increased the demand for commercial land. In recent years, scores of forestry lands are being converted into hotels and attraction, exploiting the natural resources (Hanafiah \& Hemdi, 2014). The continuous development will cause the degradation of natural environmental quality and damaging impact on the quality of life of local dwellers (Hanafiah, Abas, Jamaluddin, \& Zulkifly, 2013).

It is obvious that the relationship between tourism and the local community is sophisticated, raising few fundamental questions. What are the Pangkor Island residences' perceptions towards this development? Does responsible tourism concept is the solution? With this notion, an empirical investigation is needed to be undertaken and in line with the lack of such study particular looking in the effect of responsible tourism practices from the residence perspective.

\subsection{Literature Review}

Tourism development impact can be seen through the environmental, economic and sociocultural underpinning (Amir, Ghapar, Jamal, \& Ahmad, 2015; Hanafiah \& Harun, 2010; Yu, Chancellor, \& Cole, 2011). The development impact significantly affects the satisfaction level of a certain life domain which usually referred as the quality of life (Mohit, 2014; Sirgy, Rahtz, Cicic, \& Underwood, 2000). However, the affiliation between tourism development and residents quality of life vary due to the number of visitors, economic characteristics, the length of stay and activities (Wang \& Xu, 2015). Therefore, in order to measure how tourism developments may affect the quality of life, it is important for the researcher to understand how residents perceive their quality of life and the practices that can influence their perceptions (Aspinall, 2006; Eshliki \& Kaboudi, 2012b).

Responsible tourism practices are believed to enhance the quality of life through its strategy in channeling clear benefits to diverse stakeholders (Fadini, 2012). Responsible tourism practices include promoting equitable distribution of tourism benefits among 
communities, the business sector, and the tourists themselves (Frey \& George, 2008; Scheyvens, 1999). Responsible tourism attempts to provide a comprehensive social experience while ensuring that socio-cultural diversity maintained (Ramchander, 2003). On the other hand, local economic benefits can be maximized through increasing linkages, reducing leakages and ensuring that communities were involved in tourism planning (Murphy, 2012). Further, responsible tourism focuses on the management of natural diversity, sustainability, and appropriate systems for minimizing waste and over-consumption, integrate environmental considerations into all economic considerations, and verify any development is environmentally just (Mihalič, 2000).

As an innovative development theory, responsible tourism practices are still in the conceptual building stages. According to Harrison and Husbands (1996), responsible tourism does not refer to a variety of tourism product yet more on to the practices that sustained the tourism industry. The goals of performing responsible tourism practices are to increase the economic resilience, social-cultural validity and ecological responsibility (Panitchpakdi, 2012; Simpson, 2001). It reflects the growing trends of rising public awareness of the harmful effects and irresponsibility of numerous tourism activities (Shirotsuki, Otsuki, \& Sonoda, 2010). Nevertheless, as a newly-developed notion, responsible tourism is an interesting subject with limited study investigating the interaction between responsible tourism practices and quality of life.

\subsection{Tourism development in Tioman Island}

Pangkor Island is located in Perak state under the authority of the Manjung Municipal Council (MMC). The island can be accessed from by the sea and by the air. It has a land area of only 8 square kilometres and a population of approximately 16,571 islanders (Manjung Municipal Council). Pangkor Island became the most important tourism spot in Manjung district, but fishing, seafood, and other fishing-related products remain the major industries. At 2012, the number of tourist arrivals reached 834.278 tourists domestically as well as internationally (Manjung Municipal Council). There are six villages on this island that are Kampung Hj Hussin, Kampung Teluk Gedung, Kampung Teluk Dalam, Kampung Sungai Pinang Besar, Kampung Teluk Kecil and Kampung Teluk Nipah. Table 1 below shows the residents distribution on the Pangkor Island.

Table 1: Pangkor Island population

\begin{tabular}{lc}
\hline Village & Total Residents \\
\hline Kampung Hj Hussin & 1,395 \\
Kampung Teluk Gedung & 7,973 \\
Kampung Teluk Dalam & 2,175 \\
Kampung Sungai Pinang Besar & 1,125 \\
Kampung Teluk Kecil & 1,415 \\
Kampung Teluk Nipah & 2,488 \\
\hline Total & 16,571 \\
\hline
\end{tabular}

Source: Majlis Daerah Pangkor (2015)

\subsection{Methodology}

Information required was obtained through a self-administered questionnaire towards the residents. Variables were adapted from Ramchander (2003); (Settachai; Spenceley, 2004). 
The stratified random sampling technique was used to obtain representative from the whole group of islands for a broad range of areas. 180 questionnaires were completed by 375 respondents approached, representing 48 percent response rate for this study. In ensuring a reliable validity of the instrument used for this study, all items were filtered through factor analysis method (Pallant, 2005). Exploratory Factor Analysis (EFA) was used to gather information pertaining to inter-relationship among variables. Table below shows how the quota sampling been calculated and distributed.

Table 2: Stratified sampling calculation

\begin{tabular}{|c|c|c|c|c|}
\hline Area & Pangkor Population & $\begin{array}{l}\text { Stratified Random } \\
\text { Sampling }\end{array}$ & Sample size & Validated Questionnaires \\
\hline Kg. Hj Hussin & 1395 & $\begin{array}{c}\text { 1395/ } 16571(x) \\
375\end{array}$ & 32 & 16 \\
\hline $\begin{array}{l}\text { Kg. Teluk } \\
\text { Gedung }\end{array}$ & 7973 & $\begin{array}{c}7973 / 16571(x) \\
375\end{array}$ & 180 & 95 \\
\hline $\begin{array}{l}\text { Kg. Teluk } \\
\text { Dalam }\end{array}$ & 2175 & $\begin{array}{c}2175 / 16571(x) \\
375\end{array}$ & 49 & 23 \\
\hline $\begin{array}{l}\text { Kg. Sg. Pinang } \\
\text { Besar }\end{array}$ & 1125 & $\begin{array}{c}1125 / 16571(x) \\
375\end{array}$ & 25 & 11 \\
\hline Kg. Teluk Kecil & 1415 & $\begin{array}{c}1415 / 16571(x) \\
375\end{array}$ & 32 & 14 \\
\hline $\begin{array}{l}\text { Kg. Teluk } \\
\text { Nipah }\end{array}$ & 2488 & $\begin{array}{c}2488 / 16571(x) \\
375\end{array}$ & 56 & 21 \\
\hline Total & 16571 & & $n=375$ & $\mathrm{n}=180$ \\
\hline
\end{tabular}

\subsection{Results and Discussions}

\subsection{Factor analysis on responsible tourism practice constructs}

A total of 16 items of support for responsible tourism practices was utilized for EFA. The Kaiser-Meyer-Olkin value was 0.77 confirming the partial correlations among variables are satisfactory. The alpha coefficient for the two factors ranged from 0.86 to 0.88 .

Table 3: Factor analysis on responsible tourism practice

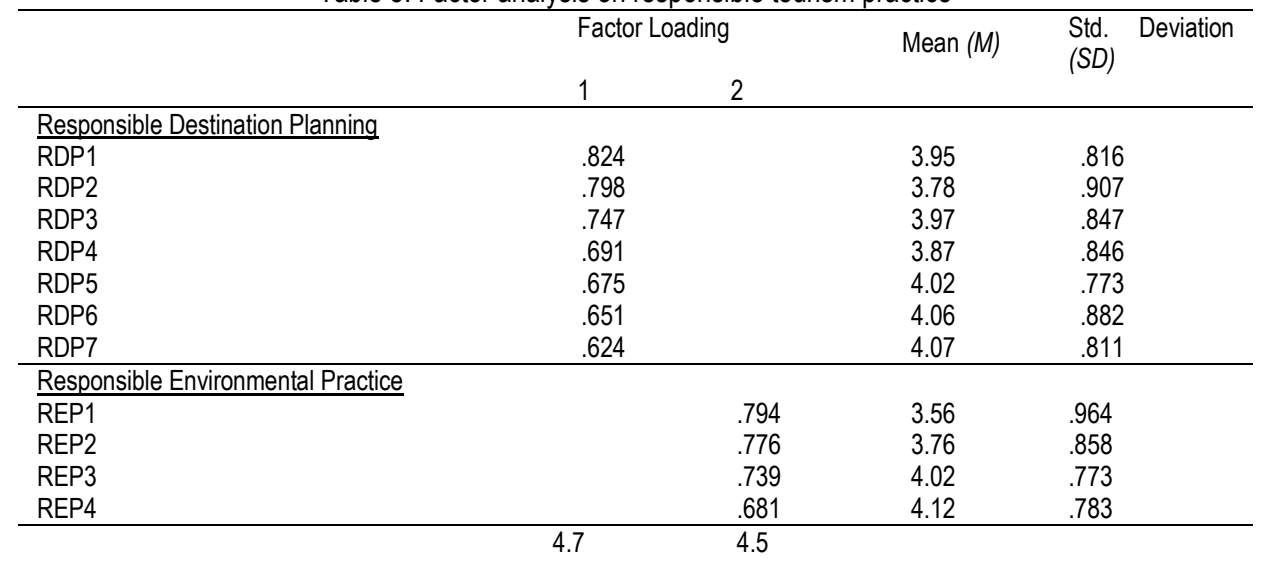




\begin{tabular}{|c|c|c|c|c|}
\hline & \multicolumn{2}{|c|}{ Factor Loading } & \multirow{2}{*}{ Mean $(M)$} & \multirow{2}{*}{$\begin{array}{l}\text { Std. Deviation } \\
(S D)\end{array}$} \\
\hline & 1 & 2 & & \\
\hline$\%$ of the variance & 25.17 & 23.79 & & \\
\hline Cum. variance (\%) & 25.17 & 48.96 & & \\
\hline Cronbach's alpha score & .885 & .861 & & \\
\hline Kaiser-Meyer-Olkin & 0.77 & & & \\
\hline
\end{tabular}

Reflecting on the responsible tourism practice mean score, the residents perceived responsible tourism practice provided the appropriate solution in combating the inappropriate development. It can be seen through their success in conducting restoration program towards the destination that damaged from the previous activities. Furthermore, the destination management practices recycle and reuse to protect the environment from pollution.

\subsection{Factor analysis on quality of life constructs}

The Kaiser-Meyer-Olkin measure of sampling adequacy test (.632) indicated that data were acceptable for factor analysis. Only one factor loaded, with loadings greater than .70. The Cronbach's alpha reliability for QOL, in general, was 0.75 , and that the factor represented $67 \%$ of the explained variance of the scale. Therefore, it was concluded that the quality of life can be measured three items, with validity and reliability. Table 4 shows the result from the explanatory factor analysis of quality of life construct.

Table 4: Factor analysis on quality of life

\begin{tabular}{lllll}
\hline & Factor Loading & Mean (M) & $\begin{array}{l}\text { Std. } \\
(S D)\end{array}$ & Deviation \\
\hline Your life as a whole & & .785 & 3.68 & .901 \\
The way you spend your life & .761 & 3.55 & .886 & \\
Your satisfaction with your life & .732 & 3.52 & .879 & \\
Happy with your life & .723 & 3.92 & .848 & \\
\hline Eigenvalues & 2.41 & & & \\
\% of variance & 67.24 & & & \\
Cronbach's alpha score & .75 & & & \\
Kaiser-Meyer-Olkin & 0.632 & & & \\
\hline
\end{tabular}

Looking on the table above, the mean score range from 3.92 to 3.52 , with the majority of the respondents was satisfied with their life $(m=3.68)$, the way they spend their life $(m=3.55)$, their life satisfaction level $(m=3.52)$ and they are happy with their life $(m=3.92)$.

\subsection{The moderating effect of responsible tourism practice}

Hierarchical multiple regression analysis was employed to test the moderating effects of responsible tourism practice on the relationship between residents' perception on tourism development and quality of life (Sheeran \& Abraham, 2003). The mean score for responsible tourism practice, perception on tourism development and quality of life were computed before conducting the regression analysis. The results of the analysis using hierarchical multiple regression were exhibited in the table below.

Table 5: Results of hierarchical multiple regression analysis

\begin{tabular}{lcl}
\hline Predictors & Model 1/Std. $\beta$ & Model 2/Std. $\beta$ \\
\hline Independent Variable: & & \\
Residents' Perception towards & $.422^{\star * *}$ & $.224^{\star * *}$ \\
\hline
\end{tabular}




\begin{tabular}{lll}
\hline Tourism Development & \\
& & \\
Dependent Variable: & & $.551^{* * *}$ \\
Quality of life & .278 & .443 \\
\hline$R^{2}$ & .273 & .435 \\
Adj. $R^{2}$ & .278 & .264 \\
$R^{2}$ Change & 35.630 & 66.376 \\
F-Change &
\end{tabular}

Note: ${ }^{*} p<0.05,{ }^{* *} p<0.01,{ }^{* * *} p<0.001$

Based on Model 1 output, residents' perception towards tourism development independently able to explain 27.8 percent $\left(R^{2}=.278\right.$, F-change $\left.=35.63, p<.001\right)$ of the variation in the quality of life. The results demonstrated that the residents' perception towards tourism development attributes ( $\beta=.422, p<.001$ ) have a significant impact on their quality of life. In the second step of hierarchical multiple regressions, the Responsible Tourism Practice was entered as moderator to influence the dependent variable. The result from Model 2 indicates that the inclusion of the moderator variable shows a significant increment in the variance explained. By looking the differences between $R^{2}$ in Model $1\left(R^{2}=.278\right)$ and Model $2\left(R^{2}=.442\right)$ statistically, it is evident that responsible tourism practices significantly moderate the relationship between residents' perception towards tourism development and the quality of life.

\subsection{Conclusion}

Tourism development indeed brought different implications towards residents' quality of life. In Pangkor Island setting, tourism development was seen to create a positive impact as it may increase the job opportunities in various sectors towards the residents. A large fraction of the Pangkor Island residents agreed that tourism development contributed towards enhancing their quality of life. Furthermore, the residents believed that responsible tourism practice is an appropriate solution in combating the pollution and inappropriate development. Responsible tourism practices also increased the quality of life through its strategy in channeling clear benefits to different stakeholders.

Finally, this study significantly contributes to the findings and understanding towards attributes in responsible tourism practice measurement. Initially, since the sampling size of the research focused on Pangkor Island, the result may not be generalized. Future research could be undertaken in foreseeing the residents' perception towards tourism development, responsible tourism practices and quality of life based on other tourism product.

\section{Acknowledgement}

The work described in this study was funded by the Research Acculturation Grant Scheme (RAGS), Ministry of Education Malaysia and Universiti Teknologi MARA Malaysia.

\section{References}

Amir, A. F., Ghapar, A. A., Jamal, S. A., \& Ahmad, K. N. (2015). Sustainable tourism development: A study on community resilience for rural tourism in Malaysia. Procedia-Social and Behavioral Sciences, 168, 116-122. 
Aspinall, A. J. (2006). Communities in Change: Social Sustainability and Tourism Development: ProQuest.

Cottrell, S. P., \& Vaske, J. J. (2006). A framework for monitoring and modeling sustainable tourism. e-Review of Tourism Research, 4(4), 74-84.

Dyer, P., Gursoy, D., Sharma, B., \& Carter, J. (2007). Structural modeling of resident perceptions of tourism and associated development on the Sunshine Coast, Australia. Tourism Management, 28(2), 409-422.

Eshliki, S. A., \& Kaboudi, M. (2012a). Community perception of tourism impacts and their participation in tourism planning: a case study of Ramsar, Iran. Procedia-Social and Behavioral Sciences, 36, 333-341.

Eshliki, S. A., \& Kaboudi, M. (2012b). Community Perception of Tourism Impacts and Their Participation in Tourism Planning: A Case Study of Ramsar, Iran. Procedia - Social and Behavioral Sciences, 36(0), 333-341. doi:http://dx.doi.org/10.1016/j.sbspro.2012.03.037

Fadini, S. (2012). Turismo e rilancio dei prodotti tipici. II pane di Matera. Atti della IV Riunione della Società Italiana Scienze del Turismo (SICTUR), 26, 27ottobre.

Frey, N., \& George, R. (2008). Responsible tourism and the tourism industry: A demand and supply perspective. Responsible tourism: critical issues for conservation and development, 107-128.

Hanafiah, M., Abas, S., Jamaluddin, M., \& Zulkifly, M. (2013). Local community outlook on tourism development in Tioman Island. Hospitality and Tourism: Synergizing Creativity and Innovation in Research, 117.

Hanafiah, M. H., \& Hemdi, M. A. (2014). Community Behaviour and Support towards Island Tourism Development. International Journal of Social, Management, Economics and Business Engineering, 8, 786-791. Retrieved from http://waset.org/publications/9997902

Hanafiah, M. H. M., \& Harun, M. F. M. (2010). Tourism demand in Malaysia: A cross-sectional pool time-series analysis. International Journal of trade, economics and Finance, 1(1), 80-83.

Harrison, L. C., \& Husbands, W. (1996). Practicing responsible tourism: international case studies in tourism planning, policy and development: John Wiley and Sons.

Kariminia, S., Ahmad, S. S., \& Hashim, R. (2012). Assessment of Antarctic Tourism Waste Disposal and Management Strategies towards a Sustainable Ecosystem. Procedia - Social and Behavioral Sciences, 68(0), 723-734. doi:http://dx.doi.org/10.1016/j.sbspro.2012.12.262

Ko, D.-W., \& Stewart, W. P. (2002). A structural equation model of residents' attitudes for tourism development. Tourism Management, 23(5), 521-530.

Liu, C.-W. (2012). Challenges of Tourism Upon the Local Community: Behaviour Settings in an Old Street in Tamsui, Taiwan. Procedia - Social and Behavioral Sciences, 68(0), 305-318. doi:http://dx.doi.org/10.1016/j.sbspro.2012.12.229

Mihalič, T. (2000). Environmental management of a tourist destination: A factor of tourism competitiveness. Tourism Management, 21(1), 65-78.

Mohit, M. A. (2014). Present Trends and Future Directions of Quality-of-Life. Procedia - Social and Behavioral Sciences, 153(0), 655-665. doi:http://dx.doi.org/10.1016/j.sbspro.2014.10.097

Murphy, P. E. (2012). Tourism: A community approach (Vol. 4): Routledge.

Nadzir, N. M., Ibrahim, M., \& Mansor, M. (2014). Impacts of Coastal Reclamation to the Quality of Life: Tanjung Tokong Community, Penang. Procedia - Social and Behavioral Sciences, 153(0), 159-168. doi:http://dx.doi.org/10.1016/j.sbspro.2014.10.050 
Pallant, J. (2005). SPSS survival guide. Open University Press, Maidenhead.

Panitchpakdi, K. (2012). Analyzing sustainability of a local community by EBS theory: The case of Kao Yi Sarn, Samut Songkram, Thailand. Journal of ASIAN Behavioural Studies, 2(4).

Pomeroy, R., Phang, K. H. W., Ramdass, K., Saad, J. M., Lokani, P., Mayo-Anda, G., . . Pido, M. D. (2015). Moving towards an ecosystem approach to fisheries management in the Coral Triangle region. Marine Policy, 51, 211-219.

Ramchander, P. (2003). Towards the responsible management of the socio-cultural impact of township tourism. Tourism and politics: global frameworks and local realities, 149-173.

Scheyvens, R. (1999). Ecotourism and the empowerment of local communities. Tourism Management, 20(2), 245-249.

Settachai, N. Responsible Community Integrated Destination Planning \& Development: Exploring Innovative and Responsive Approaches and Concepts.

Sheldon, P. J., \& Abenoja, T. (2001). Resident attitudes in a mature destination: the case of Waikiki. Tourism Management, 22(5), 435-443.

Shirotsuki, M., Otsuki, S., \& Sonoda, M. (2010). Bridging the gap between planning and environmental psychology: an application of sense of place for visioning of public policy. Asian Journal of Environment-Behaviour Studies, 1(3), 1123.

Simpson, K. (2001). Strategic planning and community involvement as contributors to sustainable tourism development. Current Issues in Tourism, 4(1), 3-41.

Sirgy, M. J., Rahtz, D. R., Cicic, M., \& Underwood, R. (2000). A method for assessing residents' satisfaction with community-based services: a quality-of-life perspective. Social Indicators Research, 49(3), 279-316.

Spenceley, A. (2004). Responsible nature-based tourism planning in South Africa and the commercialisation of Kruger National park. Ecotourism: Management and Assessment, 267-280.

Wang, S., \& Xu, H. (2015). Influence of place-based senses of distinctiveness, continuity, self-esteem and self-efficacy on residents' attitudes toward tourism. Tourism Management, 47, 241-250.

Yu, C.-P., Chancellor, H. C., \& Cole, S. T. (2011). Examining the Effects of Tourism Impacts on Resident Quality of Life. 한국관광학회 학술대회 발표논문집, 627-638. 